\title{
EFEKTIFITAS MODALITAS LATIHAN TERHADAP PENURUNAN NYERI PADA LANSIA DENGAN OSTEOARTRITIS LUTUT DI KOTA MALANG
}

\author{
Sri Sunaringsih Ika Wardojo*1, Rakhmad Rosadi ${ }^{1}$, Suci Amanati², Yudha Wahyu \\ Putra $^{3}$ \\ ${ }^{1}$ Program Studi Fisioterapi, Fakultas Ilmu Kesehatan, Unversitas Muhammadiyah Malang \\ ${ }^{2}$ Program Studi Fisioterapi, Universitas Widya Husada Semarang \\ ${ }^{3}$ Program Studi Fisioterapi, Universitas Widya Dharma Klaten \\ *Korespondensi : sunaringsih@umm.ac.id
}

\begin{abstract}
ABSTRAK
Osteoartritis merupakan penyakit sendi yang memiliki ciri khas yaitu terjadinya degradasi dari tulang rawan sendi. Terapi non farmakologis yang juga disarankan untuk penderita osteoartritis lainnya exercise yang di lakukan pada sendi lutut. Jenis exercise antara lain yang dapat dilakukan adalah home exercise, ataupun strengthening exercise yang berarti latihan penguatan yang meliputi quadriceps dan hamstring exercise, serta aerobik exercise seperti berjalan (forward walking or backward walking), bersepeda dan berenang. Penelitian ini bertujuan untuk menguji secara empiris perbandingan efektifitas pemberian terapi Fisioterapi terhadap penurunan nyeri pasien lansia dengan osteoartritis lutut. Penelitian ini memiliki desain cross-sectional dengan 30 partisipan yang merupak pasien OA lutut di Puskesmas Dinoyo, RST Soepraoen, dan RS UMM dan telah memenuhi kriteria inklusi. Semua partisipan kemudian dibagi menjadi Grup I (menerima terapi latihan selama 6 minggu), dan Grup II ( menerima terapi latihan selama 2 minggu). Instrumen penelitian yang digunakan adalah kuesioner VAS dan jenis analisa data yang dilakukan adalah uji paired T test dan independent T-test. Berdasarkan hasil uji paired $\mathrm{T}$ test masing-masing untuk Grup I dan Grup II diketahui bahwa terdapat perbedaan yang signifikan antara tingkat nyeri responden antara sebelum dan setelah dilakukan terapi latihan pada masing-masing grup. Selanjutnya ketika dibandingkan outcome terapi yang diberikan pada Grup I dan Grup II diketahui bahwa terdapat perbedaan yang signifikan antara kedua Grup, dimana Grup II relatif memiliki tingkat penurunan nyeri yang lebih baik dibandingkan dengan responden pada Grup I yang menerima terapi latihan selama 6 minggu.
\end{abstract}

Kata Kunci: Osteoarthritis, Quadriceps Strengthening Exercise, Retrowalking Exercise

\section{PENDAHULUAN}

Osteoartritis merupakan penyakit sendi yang memiliki ciri khas yaitu terjadinya degradasi dari tulang rawan sendi. Osteoartritis menghasilkan rasa nyeri yang terjadi terus-menerus, menurun atau terbatasnya fungsi dan rendahnya kualitas hidup (Petterson, et al, 2009). Pengertian osteoartritis sebagaimana dinyatakan oleh Arief Bachtiar dalam Centers for Disease Control and Prevalention (2009) adalah penyakit yang ditandai dengan nyeri, kekakuan sendi dan fungsional akibat dari kerusakan tulang rawan sendi. Nyeri yang timbul akibat adanya kerusakan jaringan tulang rawan pada daerah sendi merupakan masalah utama musuloskeletal khususnya bagi lansia. Selain nyeri, kerusakan pada sendi juga mengakibatkan kekakuan sehingga mengganggu fungsi pergerakan.Sementara WHO sebagaimana dikutip Suhendriyo (2014) menyatakan bahwa osteoartritis di seluruh dunia diderita oleh kurang lebih 
151 juta jiwa, dan di Asia Tenggara terdapat 24 juta jiwa penderita osteoartritis. Di Indonesia diperkirakan terdapat satu sampai dua juta jiwa lanjut usia yang menderita osteoartritis lutut. Menurut Sumual, Danes \& Lintong (2013) dalam penelitiannya, prevalensi osteartritis di Indonesia ditinjau dari usia yaitu pada usia 40 tahun terdapat 5\%, untuk usia 40-60 tahun memiliki presentase $30 \%$, sedangkan $65 \%$ untuk usia lebih dari 61 tahun. Sedangkan untuk prevalensi ditinjau dari jenis kelamin, osteoartritis lebih banyak terjadi pada wanita di bandingkan pria dengan presentase $25 \%$ untuk pria dan $75 \%$ untuk wanita (Mutiwara,Najirman \& Afriwardi, 2016). Menurut Pratiwi (2015) penderita osteoartritis di Kota Malang diperkirakan mencapai $21,7 \%$ dengan $6,2 \%$ terjadi pada pria dan $15,5 \%$ terjadi pada wanita. Menurut Wood et al (2013) selain usia dan jenis kelamin osteoartritis lutut juga dipengaruhi oleh berat badan berlebih (obesity) dan dampak penggunaan sendi lutut yang berlebihan, adanya kelainan pada sendi, serta cidera pada sendi lutut. Pada pasien osteoartritis terjadi penipisan hingga mengelupasnya tulang rawan sendi sehingga pada saat terjadi penekanan atau gesekan pada perm ukaan sendi terdapat nyeri dikarenakan adanya benturan antara tulang dengan tulang yang dapat mengiritasi ujung saraf pada permukaan sendi (Suriani \& Lesmana, 2013). Nyeri merupakan keluhan yang sangat umum disampaikan pasien dengan gangguan muskuloskeletal. Pada pasien dengan osteoartritis lutut sering kali mengeluhkan nyeri yang meningkat secara perlahan, adanya krepitasi dan menurunnya fungsional sendi. Adanya nyeri lutut ini menyebabkan seseorang atau penderita osteoartritis takut untuk melakukan aktivitas atau gerakan sehingga menurunkan kualitas hidupnya (Schiphof, 2011; Arya \& Jain, 2013). Menurut Jansen (2011) osteoarthritis memiliki pengaruh yang besar terhadap fungsional pasien dan kualitas hidup pasien. Osteoartritis merupakan penyakit yang umum mempengaruhi fungsional secara signifikan dan ganggu an kualitas hidup pasien serta tanggungan biaya sosial (Ouedraogo, 2014). Pada penyakit osteoartritis melibatkan kerusakan tulang rawan, tulang, ligamen dan otot serta terjadinya perubahan luas ruang sendi atau terjadinya penyempi tan ruang sendi, dan pada gambar $x$-ray akan terlihat pembentukan tulang baru atau osteofit. Tanda dan gejala yang di dapat paling dominan adalah adanya nyeri, kekakuan sendi dan kelemahan otot yang menyebabkan cacat fisik yang berimbas pada kegiatan sehari-hari penderita, permasalahan psikologi serta gangguan kualitas hidup pada penderita (Bennel \& Hindman, 2011). Peran fisioterapi pada pasien dengan gangguan muskuloskeletal menu rut Australian Physiotherapy Association (2005) yaitu dengan nonpharmacol ogical modalities yang termasuk di dalamnya Exercise Therapi, TENS, US, In fra Red, manual terapi, aquatic therapy/hydrotherapy, dan edukasi pasien. National Institute for Health and Care Excellence (2014) manajemen terapi non-pharmacological yang di anjurkan pada pasien dengan osteoartritis lutut adalah local muscle strengthening and general aerobic fitness. Terapi non farmakologis yang juga disarankan untuk penderita osteoartritis lainnya exercise yang di lakukan pada sendi lutut. Jenis exercise antara lain yang dapat dilakukan adalah home exercise, range of motion exercise $(R O M)$, strengthening exercise yang berarti latihan penguatan yang meliputi $q u$ adriceps dan hamstring exercise, serta aerobik exercise seperti berjalan (forw ard walking or backward walking), bersepeda dan berenang. Tujuan exercise ini antara lain adalah untuk memperbaiki fungsi sendi, meningkatkan lingkup gerak sendi, meningkatkan kekuatan otot, proteksi sendi dari kerusakan dengan mengurangi stres pada sendi, mencegah kecacatan dan meningkatkan kebugaran jasmani serta 
meningkatkan kualitas hidup penderita (Marlina, 2015; Jansen et al, 2011; Roddy et al, 2005). Studi literature menyatakan sebanyak 297 fisioterapis melaporkan memberikan exercise therapy pada setiap sesi terapi pada pasien dengan osteoart ritis lutut. Sebanyak 90\% tipe exercise therapy yang paling umum digunakan adalah Muscle Strengthening Exercise. Peneliti mengungkapkan bahwa pemberian exercise therapy sangat dianjurkan karena memberikan hasil yang baik dalam menurunkan nyeri yaitu sebanyak 92\%, dan peningkatan kekuatan otot sebanyak 85\% (Jamtvedt, et al, 2008). Berdasarkan penelitian lain yang telah di lakukan, aerobic exercise dalam jangka pendek ditemukan efektif untuk hasil terkait dengan gangguan tertentu misalnya menurunkan nyeri, sedangkan latihan aerobik dengan jangka waktu yang lama lebih efektif untuk hasil fungsional pasien. Latihan aerobik lebih bermanfaat dibandingkan tidak berolahraga sama sekali (Benell Hinman, 2005; Brosseau, et al, 2003). Berdasarkan hasil studi pendahuluan yang dilakukan di Dinas Kesehatan Kota Malang pada 17 Januari 2017, didapatkan jumlah data penderita osteoartrtitis di daerah Kendal Kerep Kota Malang tahun 2015 berjumlah 85 orang laki-laki dan 280 orang perempuan. Merasa tertarik dengan permasalahan yang ada pada penderita osteoar tritis terkait dengan kualitas hidup pasien osteoartritis lutut dan juga terkait intervensi Exercise yang diberikan, maka peneliti bermaksud mengadakan penelitian dengan mengangkat judul efektifitas Fisioterapi terhadap penurunan nyeri pasien lansia dengan osteoartritis lutut di Kota Malang.

\section{METODE PENELITIAN}

Jenis penelitian ini merupakan penelitian yang menggunakan desain quasi experimental yaitu dengan pre dan post test studi yang berupa menilai adanya hubungan sebab akibat antara variabel independen dan variabel dependen dalam jangka waktu tertentu. Penelitian eksperimental merupakan penelitian dengan melakukan percobaan langsung terhadap kelompok yang akan di uji. Dalam penelitian ini, peneliti akan membandingkan efektifitas Fisioterapi terhadap penurunan nyeri pasien lansia dengan osteoartritis lutut di Kota Malang.

\section{Populasi Penelitian}

Populasi dalam penelitian ini adalah pasien lansia yang terdiagnosa osteoartritis lutut di puskesmas Dinoyo, RST Soepraoen, dan RS UMM

\section{Sampel Penelitian}

Sampel pada penelitian ini 30 pasien OA lutut yang terdaftar di puskesmas Dinoyo, RST Soepraoen, dan RS UMM Kota Malang yang memmenuhi kriteria inklusi

\section{Teknik sampling}

Pada penelitian ini cara mengambil sampel pada penelitian ini menggunakan Purposive Sampling. Sampel di pilih berdasarkan kriteria inklusi yaitu:Usia 45 - 74 tahun; terdiagnosa osteoartritis lutut berdasarkan rekam medik dan diagnosa dokter; tidak mengalami gangguan kognitif; tidak memiliki berat badan berlebih; Bersedia mengikuti intervensi yang diberikan oleh peneliti selama 12 minggu dengan 36 kali pertemuan, dan bersedia menjadi responden.

\section{Waktu Penelitian}

Pengambilan data dilakukan selama 12 minggu. Dilaksanakan 2-3 kali seminggu, tergantung jenis kelompok responden, selama periode bulan Juni hingga Desember 2019.

\section{Prosedur Penelitian}

Dalam pelaksanaan penelitian ini, peneliti membagi responden menjadi 2 grup penelitian. Grup I menerima terapi latihan retrowalking dan strengthening exercise selama 6 minggu dengan intensitas latihan $3 \mathrm{x}$ seminggu, sedangkan Grup II menerima terapi latihan retrowalking dan strengthening exercise selama 12 minggu, dengan intensitas latihan $2 \mathrm{x}$ seminggu. Durasi latihan yang diberikan setiap sesi yaitu selama 30 menit. Intervensi latihan diberikan oleh tenaga fisioterapis yang berlisensi. 


\section{Instrumen}

Kuisioner Visual Analogue Scale merupakan sebuah kuisioner kesehatan yang bertujuan untuk menilai tingkat nyeri pada pasien OA lutut yang diberikan sebelum dan setelah diberikan intervensi. Skor akhir kuesioner ini berupa nilai skala nyeri $0-10$, dimana semakin tinggi skor menunjukkan semakin tinggi tingkat nyeri yang dirasakan oleh pasien

\section{Analisa Data}

Pada penelitian ini, teknik analisa data yang dilakukan untuk melihat keefektifan intervensi pada kedua grup (Grup I dan Grup II) adalah menggunakan uji Paired $T$ test dan Independent T-test.

Etika Penelitian
Dalam melaksanakan penelitian ini, peneliti telah mendapatkan izin melakukan penelitian etik kesehatan dari KEPK UMM nomer E.5.a/176/KEPKUMM/IX/2019 dan telah mendapatkan izin penelitian dari Dinas Kesehatan Kota Malang, RST Soepraoen, dan RS UMM. Selain itu, sebelum dilaksanakan semua prosedur penelitian, semua responden telah dijelaskan terkait prosedur penelitian, konsekuensi penelitian, dan setiap responden yang berkenan selanjutnya menandatangani lembar inform consent.

\section{HASIL PENELITIAN}

Data mengenai karakteristik responden berdasarkan usia dapat dilihat pada tabel 1

Tabel 1. Karakteristik Responden Berdasarkan Usia

\begin{tabular}{ccccccc}
\hline \multirow{2}{*}{ Kelompok } & \multirow{2}{*}{$\begin{array}{c}\text { Jumlah } \\
\text { Responden }\end{array}$} & Min & Maks & Mean & St.dev \\
\cline { 3 - 7 } & 15 & 45 & 65 & 57,87 & 5,73 \\
\hline Grup I & 15 & 47 & 65 & 57,47 & 5,29 \\
\hline Grup II & & & & &
\end{tabular}

Berdasarkan tabel 1 distribusi usia responden pada Grup I memiliki karakteristik usia minimal 45 tahun, usia maksimal 65 tahun dan rata-rata distribusi usia 58 tahun. Sedangkan pada Grup II memiliki karakteristik usia minimal 47 tahun, usia maksimal 65 tahun dan ratarata usia 58 tahun.

Tabel 2 ini menujukkan hasil uji paired $t$ test untuk efektivitas terapi latihan pada responden Grup I terhadap penurunan nyeri. Hasil analisis diperoleh nilai signifikansi $0,000(\mathrm{p}<0,05)$, nilai Sig. (2-tailed) < taraf nyata $(\alpha)$ sehinggan dapat ditarik kesimpulan bahwa H0 ditolak, dengan demikian dapat disimpulkan bahwa ada perbedaan signifikan pada efektivitas latihan selama 6 minggu terhadap penurunan nyeri pada pasien osteoarthritis lutut.

Tabel 2. Hasil Uji Paired T Test Group I Sig (2-tailed)

Penurunan Nyeri 0,000

Tabel 3 ini menujukkan hasil uji paired t test untuk efektifitas latihan selama 12 minggu terhadap penurunan nyeri pada pasien osteoarthritis lutut.

Tabel 3. Hasil Uji Paired T Test Group II Sig (2-tailed)

Penurunan Nyeri $\quad 0,000$

Hasil analisis uji paired t test pada Grup II dengan program SPSS, diperoleh nilai signifikansi $0,000(\mathrm{p}<0,05)$, nilai Sig. (2-tailed) $<$ taraf nyata $(\alpha)$ sehinggan dapat ditarik kesimpulan bahwa H0 ditolak, dengan demikian dapat disimpulkan bahwa ada perbedaan signifikan pada efektivitas latihan selama 12 minggu terhadap penurunan nyeri pada pasien osteoarthritis lutut.

Tabel 4. ini menujukkan hasil uji independent $t$ test untuk efektivitas latihan terhadap penurunan nyeri pada pasien osteoarthritis lutut. 
Tabel 4. Hasil Uji Independent T Test

\begin{tabular}{ll}
\hline & Sig (2-tailed) \\
\hline Penurunan Nyeri & 0,007 \\
\hline
\end{tabular}

Hasil analisis uji independent t test sesudah latihan selama 12 minggu dan 6 minggu dengan program SPSS, diperoleh nilai signifikansi $0,007(\mathrm{p}<0,05)$, nilai Sig. $(2$-tailed $)<$ taraf nyata $(\alpha)$ sehinggan dapat ditarik kesimpulan bahwa H0 ditolak, dengan demikian dapat disimpulkan bahwa ada perbedaan signifikan pada efektifitas terapi latihan terhadap penurunan nyeri pada pasien osteoarthritis lutut. Serta menurut hasil perbandingan selisih hasil kedua grup tersebut didapatkan perbandingan hasil yang cukup berbeda, hasil nilai selisih pre-post Grup II lebih besar daripada hasil nilai selisih pre-post Grup I, sehingga dapat disimpulkan bahwa ada perbedaan efektifitas terapi latihan, dimana terapi latihan selama 12 minggu yang diberikan pada partisipan Grup II lebih baik menurunkan nyeri daripada responden pada Grup I yang menerima latihan selama 6 minggu.

\section{PEMBAHASAN}

Studi ini menyelidiki efek dari periode intervensi yang berbeda pada intensitas nyeri. Peneliti berhipotesis bahwa individu dengan OA lutut yang menerima intervensi jangka panjang (12 minggu) akan menunjukkan efek yang lebih baik pada pereda nyeri, fungsi fisik pada aktivitas sehari-hari, yang lebih baik dibandingkan dengan individu yang diberikan terapi latihan selama periode 6 minggu dengan durasi $3 \mathrm{x}$ seminggu.

Berdasarkan hasil penelitian, hal ini mendukung hipotesis awal kami bahwa pelaksanaan latihan olah raga untuk penderita OA lutut dalam waktu 12 minggu secara terus menerus memberikan efek yang signifikan dan lebih baik dalam meningkatkan fungsi lutut yang tercermin dari skor WOMAC dan CST, mengurangi nyeri, dan juga meningkatkan kualitas hidup setelahnya. 12 minggu dibandingkan dengan peserta yang menerima intervensi
$<12$ minggu. Temuan ini juga didukung dengan penelitian sebelumnya bahwa penyelesaian latihan ini telah sejalan dengan peningkatan fungsi lutut dan nyeri yang dilaporkan sendiri.

Sebuah studi eksperimental di antara 72 pasien OA lutut dibagi menjadi 2 kelompok yang secara acak ditugaskan dengan program latihan penguatan pinggul atau kaki selama 12 minggu menghasilkan program penguatan pinggul dan kaki yang meningkatkan nyeri lutut (perbedaan ratarata -7.79), fungsi kemampuan berjalan, dan kualitas hidup (Lun et al., 2015). Selain itu, studi RCT dengan 102 partisipan yang diberikan latihan penguatan 3 kali seminggu selama 16 minggu, juga menghasilkan peningkatan kemampuan fungsional dan mengurangi nyeri sendi lutut pada individu dengan OA lutut sebesar 28\% menjadi 58\% (Topp et al., 2002). Meskipun kedua penelitian sebelumnya memiliki periode intervensi yang berbeda(12 dan 16 minggu), namun dapat disimpulkan bahwa mereka semua merancang intervensi penguatan untuk individu OA lutut yang memiliki hasil yang sama dalam meningkatkan nyeri lutut dan intensitas lutut. Dengan demikian, periode intervensi 12 minggu cukup lama untuk memberikan efek yang baik untuk meningkatkan intensitas nyeri dan fungsi fisik. Juga, penjelasan yang mungkin dari peningkatan ini mungkin karena intervensi latihan yang diberikan yang meningkatkan kekuatan otot paha depan dan selanjutnya meningkatkan stabilitas sendi fungsional, penyerapan guncangan, dan penurunan gaya dasar selama aktivitas kehidupan sehari-hari, seperti berjalan (Ağlamiş et. al., 2009; Diracoglu et al., 2005; M Fransen et al., 2008; Marlene Fransen et al., 1997; Lim et al., 2008; Pang \& Lau, 2010). Lebih lanjut, efek olahraga segera setelah pengobatan, yang bukti berkualitas tinggi menunjukkan bahwa latihan terapeutik di darat memberikan manfaat jangka pendek yang bertahan setidaknya dua hingga enam bulan setelah penghentian pengobatan formal dalam hal 
mengurangi nyeri lutut, dan bukti kualitas sedang menunjukkan peningkatan fungsi fisik pada orang dengan OA lutut (M Fransen et al., 2008). Perbandingan efek intervensi antara berjalan aerobik dan latihan penguatan paha depan berbasis rumah dengan kelompok kontrol nonlatihan menunjukkan bahwa berjalan aerobik dan latihan penguatan paha depan berbasis rumah mengurangi intensitas nyeri dan kecacatan dari OA lutut (Roddy et al., 2005).

Selain itu, terkait dengan kegiatan sholat, karena belum ada pengukuran khusus yang dianalisis secara detail gerakannya, namun secara sederhana dapat dianalisis melalui lima item yang tercakup dalam bagian fungsi fisik di WOMAC yang menilai kesulitan beberapa gerakan akibat lutut. nyeri, yaitu: bangun dari duduk, berdiri, membungkuk ke lantai, duduk, dan melakukan tugas-tugas pusat perhatian. Lebih lanjut, hasil skor 5 item dari WOMAC menunjukkan bahwa ada peningkatan yang signifikan pada fungsi lutut ini setelah diberikan latihan, terutama setelah 12 minggu intervensi yang menunjukkan ukuran efek yang lebih besar pada kegiatan sholat muslim untuk kelompok I dibandingkan dengan kelompok lain. . Selama gerakan sholat Muslim, mereka perlu menekuk lutut dalam gerakan fleksi penuh, dan selama fleksi lutut dalam, momen dan kekuatan besar mengakibatkan tekanan tinggi pada sudut fleksi yang tinggi. Beban ini dapat mempengaruhi perubahan patologis pada sendi dan merupakan faktor penting dalam meningkatkan tingkat nyeri untuk OA lutut (Hefzy et al., 1998; Nagura et al., 2002). Sementara, intervensi latihan yang diberikan mungkin membantu untuk menghindari kekuatan sendi yang merusak dan kemungkinan akan dikaitkan dengan penurunan tingkat nyeri dan peningkatan fungsi lutut (Susko \& Fitzgerald, 2014).

Namun untuk penelitian ini, kegiatan pelatihan memiliki ukuran efek yang relatif kecil untuk kualitas hidup setelah 12 minggu, seperti yang dijelaskan oleh penelitian lain (Ağlamiș et al., 2009; Baker et al., 2001; Foley et al., 2003; Marlene Fransen et al. al., 2003) bahwa kegiatan pelatihan akan memiliki efek yang efektif pada kualitas hidup dalam 4 sampai 6 bulan setelah intervensi diberikan, karena latihan akan berdampak panjang untuk meningkatkan kapasitas fungsional, nyeri dan keadaan kesehatan secara umum.

Penelitian ini memiliki keterbatasan karena hasil yang dapat digeneralisasikan karena ukuran sampel dianggap kecil karena tingginya angka putus sekolah. Namun demikian, hasil penelitian ini dapat memberikan wawasan khususnya bagi penelitian fisioterapi di Indonesia, dengan melakukan latihan senam selama 12 minggu ternyata berpengaruh signifikan terhadap peningkatan fungsi fisik dan kualitas hidup, serta mengurangi nyeri yang berujung pada peningkatan kemampuan dalam melakukan aktivitas sehari-hari.

\section{DAFTAR PUSTAKA}

Adithya L, Lafian R, Fatwa M. (2016). Uji Valditas dan Reliabilitas Instrumen SF-36 Untuk Mengukur Kualitas Hidup Pasien Diabetes Melitus. Skripsi. Akademi Farmasi ISFI Banjarmasin.

Alghadir. A., Anwer. S. (2016). Effect of retro and forward walking on quadriceps muscle strength, pain, function, and mobility in patients with knee osteoarthritis: a protocol for a randomized controlled trial. Alghadir and Anwer BMC Musculoskeletal Disorder. 17: 161.

Ali W.A.H. (2014). Prevalensi dan distribusi osteoartirtis lutut berdasarkan karakteristk sosiodemografi dan faktor resiko di wilayah kerja puskesmas susut I, kecamatan susut, kabupaten bangli pada tahun 2014. Skripsi.

Pendidikan Dokter Fakultas Kedokteran, Universitas Udayana. Arisman. (2004). Gizi dalam Daur 
Kehidupan. Jakarta : EGC.

Ansar, Sudaryanto. (2011).

Biomekanik Osteokinematika dan Arthokinematika.

Kementrian Kesehatan RI

Politeknik Kesehatan Makassar.

Anwer S., Alghadir A. (2014). Effect of Isometric Quadriceps Exercise on Muscle Strength, Pain, and Function in Patients with Knee Osteoarthritis: A Randomized Controlled Study. Journal Physical Therapy Science. 26(5), 745-748.

Arya RK, Jain Vijay. (2013). Osteoarthritis of the knee joint: an overview, Journal, Indian Academy of Clinical Medicine 2013. 14(2): 154-62

Australian Physiotherapy Association. (2005). Physiotherapy $\mathrm{n}$ the management of arthritis and musculosceletal conditions. APA Position Statement.

Bachtiar Arief. (2010). Pengaruh ekstrak jahe terhadap tanda dan gejala osteoartritis pada pasien rawat jalan di puskesmas pandan wangi kota Malang. Skripsi.

Universitas Indonesia.

Baechle TR, \& Earle RW. (2008). Essentials of Strength training and conditioning $\left(3^{r d}\right.$ ed). Champaign, IL : Human Kinetics

Bates Barry T., Dufek Janet S., Grolle C., Grolle E. (2000). Retrowalking for Rehabilitation and Fitness. http://darkwing.uoregon.edu/ diakses pada 17 Januari 2017

Bennell KL, Hinman RS. (2011). A review of the clinical evidence for exercise in osteoarthritis of the hip and knee. J Sci Med Sport 2011; 14: 4-9.

Bennel K, Hinman R. (2005). Exercise as a treatment for osteoarthritis. Curr Opin Rheumatol. 17(5); 634-40.

Black, Joyce. M., Hawks, Jane. H. (2014). Keperawatan Medikal Bedah: Manajemen Klinis Untuk Hasil Yang Diharapkan, Edisi 8-Buku 1 (dr. Rizal Ashari N, dr. Shanti Citra Eka: Penerjemah). Jakarta: Salemba Medika

Blagojevic. M., Jinks. C., Jeffery A., Jordan KP. (2009). Risk Factors for onset of osteoarthritis of the knee in older adults: a systematic review and meta- analysis. Osteoarthritis and Cartilage. 18(1) 24-33.

Brosseau L., MacLeay L., Robinson V., Wells G., Tugwell P. (2003). Intensity of exercise for the treatment of osteoarthritis. Cochrane Database Syst Rev 2003.

Chairunniisa Siti. (2016). Hubungan antara terapi latihan fisik terhadap kualitas hidup pasien osteoartirtis di RSUD DR. Zainoel Abidin Banda Aceh.

Disertasi. Fakultas Kedokteran Universitas Syiah Kuala.

Conaghan. P.G., Porcheret M., Kingsbury SR., Gammon A., Soni A., Hurley M. Et al. (2014). Impact and therapy of osteoarthritis: the arthritis care OA Nation 2012 survey. Clinical Rheumatologi. 34(9). 1581-1588.

Culvenor AG., Engen CN., Oiestad BE., Engebretsen L., Risberg MA. (2013). Defining the presence of radiographic knee osteoarthritis: a comparison between tke Kellgren and Lawrence system and OARSI atlas criteria. Knee Surg Sports Traumatol Arthrosc.

Darmojo, Martono. (2006). Geriatri. Jakarta : Yudistira.

Depkes RI. (2006). Pedoman Pembinaan Kesehatan Jiwa Usia Lanjut bagi Petugas Kesehatan. Jakarta: Depkes.

Dinesh Bhatia., Bejarano T., Novo M. (2013). Current interventions in the management of knee osteoarthritis. Journal of pharmacy \& bioallied sciences. 5(1) 30-38.

Effendi, F \& Makhfudli. (2009). Keperawatan

Kesehatan 
Komunitas: Teori dan Praktek Dalam Keperawatan. Jakarta: Salemba medika.

Evelyn C.Pearce. (2008). Anatomi dan fisiologi untuk para medis. Jakarta: PT Gramedia

Fatma.(2010).Gizi Usia Lanjut. Jakarta: Erlangga

Hafez, A.R., Johani, A.H.A., Zakaria, A.R., Ahaideb, A.A., Burgadda, S., Melam. G. R., etal (2013). Treatment of Knee Osteoarthritis in Relation to Hamstring and Quadriceps Strength. Journal of Nocel Physiotherapy Science. 25: 1401- 1405.

Hidayat, A.A.A. (2007). Metode Penelitian Keperawatan Dan Teknik Analisa Data.

Surabaya : Salemba Medika

Hochberg. MC. Altman RD., April KT., Benkhalti M., Guyatt., McGowan J., Et al. (2012). American college of rheumatology 2012 recommendations for the use of nonpharmacologic and pharmaclogic therapies in osteoaarthritis of the hand, hip, and knee. Arthritis Care Res. 64(4): 6574.

Hoffman Matthew. (2014). Picture of The Knee. WebMD http://www.webmd.com/, diakses pada 17 Januari 2017.

Hussein N.A.M.M., Saad M.M.A.H., Sawey H.A.H.E. (2015). Effect of combined balance isotonic resistive exercise versus isotonic resistive exercise alone on proprioception and stabilizing reactions of Quadriceps and hamstrings and functional capacity of knee osteoarthritis patients. Journal of Nocel Physiotherapy. 5(5). 1-8.

Imoto AM, Peccin MS, Trevisani VFM. (2012). Quadriceps Strengthening Exercises are Effective in Improving Pain, Function and Quality of Life in Patients with Osteoarthritis of The Knee. Acta
Ortop Bras. 20(3); 174-9

Jansen MJ., Viechtbauer W., Lenssen AF., Hendriks EJM., Bie RA. (2011). Stregth training alone, exrcise therpy alone, and exercise therapy with passive manual mobilisation each reduce pain and disability in people with knee osteoarthritis: a systematic review. Journal of Physiotherapy 57: 11-20.

Jarntvedt Gro., Dahm KT., Christie A., Moe RH., Haarvaedsholm E., Holm I. Et al. (2008). Physical Therapy Interventions for Patients With Osteoarthritis of The Knee : Overview of Systematic Reviews. Physical Therpy. 88(1): 123- 36.

Jati Destur P. (2015). Pengertian dan Klasifikasi Lansia (Lanjut Usia). https://senyumperawat.com, diakses pada 17 Januari 2017

Kaplan W, Wirtz VJ., Teeuwisse AM., Stolk P., Duthey B., Laing R. (2013). Priority Medicines for Europe and The World 2013 Update. $\quad W H O$ Library Cataloguing-in-Publication Data.

Kesemenli CC., Sarman H., Baran T., Memisoglu K., Binbir I., Savas Y., Isil C. Boyraz., Koc B. (2014). A new isometric qadricepsstrengthening exercise using EMG biofeedback. Int J Clin Exp Med. 7(9); 2651-2655.

Krunoslav. (2014). Bodybuilding Anatomy - Quadriceps Femoris. Bodybuilding Wizard. http://bodybuilding-wizard.com/, diakses pada 17 Januari 2017

Litwic Anna., Edwards MH., Dennison EM., Cooper C. (2013). Epidemiology and Burden of Osteoarthritis. British Medical Bulletin. 105(1); 185-199.

Marlina, TT. (2015). Efetifitas latihan lutut terhadap penurunan intensitas nyeri pasien ostoartritis lutut di Yogyakarta. Jurnal Keperawatan Sriwijaya. 2(1); 44-54.

Mayer F., Rosenberger FS., 
Carlsohn A., Cassel M., Muler S., Scharhag J. (2011).

The Instensity and effects of strength training in the elderly. Dtsch Artzteb Int 2011. 108(21); 359-64

Melani Fransisca. (2016). Evaluasi Kualitas Hidup Responden Hipertensi Mengguakan Instrumen SF-36 : Kajian Faktor Usia dan Tingkat Penghasilan Di Kecamatan Kalasan, Sleman, DIY. Skripsi. Universitas Sanata Dharma Yogyakarta.

Meyler Zinovy. (2011). Knee Anatomy. Arthritis Health. http://www.arthritis- health.com, diakses pada 17 Januari 2017

Murti TW. (2014). Pengaruh Manual Terapi Traksi Terhadap Peningkatan Aktivitas Fungsional Pada Osteoartritis Lutut. Skripsi. Universitas Muhammadiyah Surakarta.

Mutiwara E,. Najiman., Afriwadi. (2016). Hubungan indeks massa tubuh dengan derajat kerusakan sendi pada pasien osteoartitis lutut di RSUP Dr. M. Djamil Padang. Jurnal Kesehatan Andalas. 5(2).

National Clinical Guideline Centre. (2014). Osteoarthritis Care and Management in adults. National Institute for Health and Cara Excellence.

Nisfiannoor, Muhammad. (2009). Pendekatan Statistika Modern Untuk Ilmu Sosial.

Jakarta : Salemba Humanika.

Notoatmodjo, Soekodjo. (2010). Metodologi Penelitian Kesehatan. Jakarta : Rineka Cipta

Nugraha A. Kambayana G. (2017). Prinsip Latihan Penderita Osteoartritis. Bagian Ilmu Penyakit Dalam, Fakultas Kedokteran Univeritas Udayana. 44(2).

Nuhonni SA. (2016). Latihan Berjalan Mundur Retrowalking Exercise.
DR. Berlian Siagian. Diakses pada 18 November 2016.

Nursalam. (2010). Metodologi Penelitian Ilmu Keperawatan. Jakarta : Salemba Medika

Oktarina Intan. (2016). Kualitas Hidup Pada Lanjut Usia yang Mengalami Sakit Osteoartritis di Desa Gumpang Kecamatan Kartasura. Skripsi. Universitas Muhammadiyah Surakarta.

Ouedraogo, D.D., Tiendrebeogo J., Kenagnon ADS., Kabore F., Compaore C., Drabo YJ., Et al. (2014) Quality of Life of Patients with Knee Osteoarthritis with Questionnaire OAKHQOL (OsteoArthritis of Knee Hip Quality of Life) in Rheumatology Consultation in Burkina Faso (West Africa). Open Journal of Rheumatology and Autoimmune Diseases. 4. 219-225.

Petterson, S.C., Mizner, R.L., Stevens JE., Raisis L., Boden A., Newcomb W., Et al. (2009). Improved Function From Progressive Strengthening Interventios After Total Knee Arthroplasty: A Randomized Clinical Trial With an Imbedded Prospective Cohort. Arthritis \& Rheumatism, 61(2), 174-183.

Physio Advisor Staff.(2016). Quadriceps Strengthening Exercises.

www.physioadvisor.com.au/ diakses pada 17 Januari 2017 Pratiwi Anisa I. (2015). Diagnosis and Treatment Osteoarthritis. $J$ Majority. 4(4); 20-27.

Rand Health. (2012). 35-item short form survey $\quad(S F-36) \quad$ Scoring Instructions. http://www.rand.org, diakses pada 12 Desember 2016

Roddy. E., Zhang. W., \& Doherty. (2005). Aerobic walking or strengthening exercise for osteoarthritis of the knee: a systematic review. Ann Rheum Dis. 64, 544- 548.

Salih S, Sulton P. (2013). Obesity, 
knee steoarthritis and knee arthroplasty: a review.

BMC Spots Science, Medicine \& Rehabilitation. 5(25).

Schiphof Dieuwke., Bianca M., Klerk de., Waarsing JH., Hofman A., Ginai AZ., Et al. (2011). Risk factors and their association with MRI osteoarthritic features in female knees without radiographic signs of osteoarthritis. Risk factors and MRI osteoarthritis features. 6. 7788.

Setiani WD. (2012). Hubungan Antara Riwayat Penyakit, Asupan Protein dan Fakor

- Faktor Lain dengan Status Gizi Peserta Posyandu Lansia di Kecamatan Grogol Petamburan Jakarta Barat Tahun 2011. Skripsi. Fakultas Kesehatan Masyarakat Universitas Indonesia.

Setianto, B. (2007). Pengetahuan Pelayanan Fisik Lanjut Usia. www.pjnhk.go.id, diakses pada 12 Desember 2016

Shahzad Sehar. (2016). Best Knee Strengthening Exercise. Health and Fitness Lines.

http://www.fitnesslines.com, diakses pada 7 Desember 2016.

Shankar P, Renukadevi M., Bhandiwad RMA., Pai H. (2013). Effectiveness of Retrowalking in Chronic Osteoarthritis of Knee Joint. Innovative Jurnal of Medical and Helath Science. 19-22.

Silas C, Tobing SDA. (2012). Evaluation of Quality of Life Using Short Form-36 and Visual Analogue Scale After Posterior Instrumentation and Fusin in Tuberculous Spondylitis Patients at Cipto Mangunkusumo Hospital. Journal of Indonesian Orthopaedic. 40(2); 21-24.

Soeroso J., Isbagio H., Kalim H., Broto R., Pramudiyo R. (2006).Osteoartritis.

Dalam: Sudoyo AW, Setiyohadi B,
Alwi I, Simadibrata M, Setiati S, editors. Buku Ajar Ilmu Penyakit Dalam. 4th ed. Jakarta: Pusat Penerbitan Ilmu Penyakit Dalam FKUI; 2006.p.1195-201.

Sonjaya MR., Rukanta D., Widayanto. (2014). Karakteristik Pasien Osteoarthritis Lutut Primer di Poliklinik Ortopedi Rumah Sakit Al-Islam Bandung Tahun 2014. Skripsi. Universitas Islam Bandung.

Sport Injury Clinic.(2011). Quads Exercise - isometric quads prone. www.sportsinjuryclinic.net, diakses pada 16 Desember 2016 Sugiyono. (2013). Metode Penelitian Pendidikan. Bandung: Alfabeta

Suhartin P. (2010). Teori Penuaan, Perubahan pada Sistem tubuh dan Implikasinya pada Lansia. Fakultas Kedokteran. Universitas Diponegoro.

Suhendriyo, (2014). Pengaruh Senam Rematik Terhadap Pengurangan Rasa Nyeri Terhadap Penderita Osteoartritis Lutut di Karangasem Surakarta. Jurnal Terpadu Ilmu Kesehatan. 3(1), 1-6.

Sumual, A.S., Danes V.R., Lintong F. (2013). Pengaruh berat badan terhadap gaya gesekan dan timbulnya osteoartritis pada orang diatas 45 tahun di RSUP Prof. Dr. R. D Kandou Manado. Jurnal ebiomedik (eBM), 1(1), 140-146.

Suriani Sri, Lesaman Indra. (2013). Latihan Theraband lebih baik menurunkan nyeri daripada latiha Quadriceps Bench pada Osteoartritis Genu. Jurnal Fisioterapi. 1. 13.

Syaifuddin. (2010). Anatomi Tubuh Manusia untuk Mahasiswa Keperawatan.

Jakarta: Salemba Medika.

Tanaka R, Ozawa J, et al. (2015). Does Exercise Therapy improve the health-related quality of life of 
people with knee osteoarthritis; a Systematic review and metaanalysis of randomized controlled trials. Journal Physical Therapy Science. 27(10); 3309-3314.

Tschirpke Carol. (2014). Avoid a Hamstring Leg-acy. Biosynchronistics Physics for Health.

https://biosynchronistics.com/ diakses pada 17 Januari 2017

Vasoya R, Vikani R. (2015). Effect of retrowalking in osteoarthritis of knee. School of Physiotherapy R K University.2015:1- 60. http://rku.ac.in/spt/wpcontent/uploads/2015/08/group$\underline{\text { 42.pdf }}$. diakses pada, 19 Desember 2016

Wadhwa DN, Hande DN. (2016). Effects of Retrowalking on Osteoarthritis of Knee in Geriatric Population. Journal of Sports and Physical Education. 3(2); 37- 43.

Ware JE, Sherbourne CD. The MOS 36Item Short Form Health Survey (SF 36). Conceptual Framework and Item selection. Medical Care. 1992; 30:473-83

Wood AMD., Brock TM., Heil K., Holmes R., Weuste A. (2013). A review on the management of Hip and Knee Osteoarthritis. International Journal of Chronic Diseases. 2013. 10.

Zhang Y. Jordan Joanne M. (2010). Epidemiology of Osteoarthritis. Clin Geriatric Med. 26(3); 355369. 